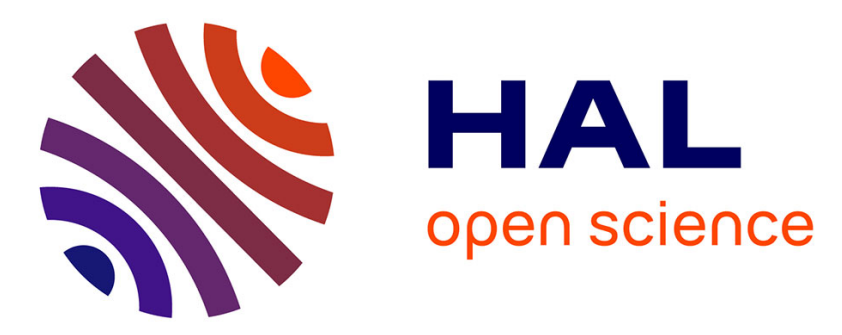

\title{
Callable Convertible Bonds in Sequential Financing: Evidence on the Western European Market
}

\author{
Olivier Adoukonou, Florence André, Jean-Laurent Viviani
}

\section{To cite this version:}

Olivier Adoukonou, Florence André, Jean-Laurent Viviani. Callable Convertible Bonds in Sequential Financing: Evidence on the Western European Market. Journal of Multinational Financial Management, 2018, 45, pp.35-51. 10.1016/j.mulfin.2018.04.001 . halshs-01767575

\section{HAL Id: halshs-01767575 \\ https://shs.hal.science/halshs-01767575}

Submitted on 16 Apr 2018

HAL is a multi-disciplinary open access archive for the deposit and dissemination of scientific research documents, whether they are published or not. The documents may come from teaching and research institutions in France or abroad, or from public or private research centers.
L'archive ouverte pluridisciplinaire HAL, est destinée au dépôt et à la diffusion de documents scientifiques de niveau recherche, publiés ou non, émanant des établissements d'enseignement et de recherche français ou étrangers, des laboratoires publics ou privés. 


\section{Accepted Manuscript}

Title: Callable Convertible Bonds in Sequential Financing:

Evidence on the Western European Market

Authors: Adoukonou Olivier, Andre Florence, Viviani

Jean-Laurent

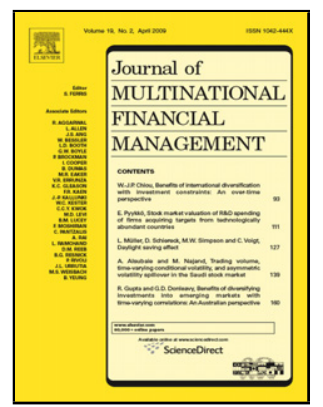

PII:

S1042-444X(17)30272-4

DOI: https://doi.org/10.1016/j.mulfin.2018.04.001

Reference: MULFIN 552

To appear in: J. of Multi. Fin. Manag.

Received date:

$17-11-2017$

Revised date:

6-4-2018

Accepted date:

$10-4-2018$

Please cite this article as: Olivier, Adoukonou, Florence, Andre, Jean-Laurent, Viviani, Callable Convertible Bonds in Sequential Financing: Evidence on the Western European Market.Journal of Multinational Financial Management https://doi.org/10.1016/j.mulfin.2018.04.001

This is a PDF file of an unedited manuscript that has been accepted for publication. As a service to our customers we are providing this early version of the manuscript. The manuscript will undergo copyediting, typesetting, and review of the resulting proof before it is published in its final form. Please note that during the production process errors may be discovered which could affect the content, and all legal disclaimers that apply to the journal pertain. 


\title{
Callable Convertible Bonds in Sequential
}

Financing: Evidence on the Western European

Market

\author{
ADOUKONOU Olivier \\ CREM, Université d'Angers, olivier.adoukonou@univ-angers.fr \\ 2 Rue de Rennes, 49100 Angers, FRANCE
}

ANDRE Florence

Univ Rennes, CNRS, CREM - UMR 6211, F-35000 Rennes, France, florence.andre@univ-rennes1.fr

11 rue Jean Macé, 35708 Rennes, FRANCE

VIVIANI Jean-Laurent

Univ Rennes, CNRS, CREM - UMR 6211, F-35000 Rennes, France, jean-laurent.viviani@univ-rennes1.fr

11 rue Jean Macé, 35708 Rennes, FRANCE

Highlights 
- At call date, calling firms have no more capital expenditure than non-calling firms.

- Calling firms issue more equity than non-calling firms do.

- Investment is greater for in-the-money call than for out of the money call.

Abstract: The objective of the paper is to test empirically the Mayers (1998) sequential financing hypothesis stating that companies issue callable convertible debt to overcome the problem of overinvestment (Jensen, 1986) that could arise in a sequential investment setting. As a result of this theory we should observe higher investment and financing activities at the exercise call dates especially if it is in the money. Based on a sample of 277 Callable Convertible Bonds issued by non-financial firms in Western Europe between 1994 and 2009, comprising 161 callable convertible bonds being subject to forced conversion (calling subsample) and 116 non-called convertible bonds (non-calling subsample) and using classical and difference-in-differences methodologies, we find evidence only weakly in line with the sequential financing hypothesis of Mayers (1998). For the calling firms, we, in general, do not observe significant positive changes in capital expenditure at call dates that are greater than those of the non-calling firms. We observe a significant difference in new equity issuances only for the comparison between calling and non-calling firms. Unlike Alderson et al. (2006), we find that in the money calling firms increase their investment around the convertible bonds calls more than out of the money calling firms. We also find a positive impact of the call decision on the change of the new debt issuance at the call dates.

Keywords: convertible bonds, sequential financing hypothesis

\section{JEL classification: G32}

\section{Introduction}

Since the 70s numerous research studies have focused on understanding why companies issue convertible bonds. These studies have recently been reviewed by Dutordoir et al. (2014). 
These authors give an overview of competing theoretical explanations for convertible bond issuance divided in two groups. In the first group, they present four theoretical models: the risk shifting theory of Green (1984), the risk uncertainty theory of Brennan and Kraus (1987) and Brennan and Schwartz (1988), the backdoor-equity theory of Stein (1992), and the sequential financing theory of Mayers (1998). In the second group of papers, authors argue that convertibles are issued in response to investors' demand consideration (Lewis et al., 2001; Brown et al., 2012; De Jong et al., 2013). A convertible bond is a hybrid-financing tool that combines the features of bonds and stocks in one instrument and gives the holder the right to convert his bond into a predetermined number of stocks (voluntary conversion). Convertible bonds combine the characteristics of equity and bonds, and include embedded options such as the call feature, which is the most common. Such bonds, referred to as "callable convertible bonds" allow the issuing firm to call back its debt, in exchange of a payment agreed in advance when the conversion value reaches the call price (forced conversion).

In this paper, we focus on testing the sequential financing theory of Mayers (1998) by investigating whether the exercise of the call option by issuers is associated with significant investing and financing activities. Mayers (1998) considers convertible bonds as a tool to reduce agency problems between managers and shareholders. If the company has a sequence of investment opportunities, convertible bonds are more suitable than long-term straight bonds for financing real options since they can overcome overinvestment problems (Jensen, 1986) by redeeming bonds and returning cash to bondholders when the investment option turns out to be worthless. If the investment turns out to be valuable, the convertible debt is converted into common equity. To overcome this problem of overinvestment incentives, firms can issue a sequence of short-term debts. But in this setting, rolling over short-term debt entails higher issuance costs. In this context, the callable convertible bond is preferable to classical sequential financing. The presence of a call option (and in a lesser extent a conversion option) can simultaneously reduce issue costs (generated by sequential financing) and control overinvestment incentives (Jensen, 1986).

Mayers' (1998) theory is worth being empirically tested since it is the only one to link company financing and investing activities and since most empirical tests have been conducted on the US market only, and by very few authors including Mayers (1998), Alderson et al. (2006) and King and Mauer (2014). Moreover, the empirical evidence is mixed. Mayers (1998) finds empirical support for his model followed by King and Mauer (2014), but the results of Alderson et al. (2006) are much less clear. The work of Korkeamaki and Moore (2004), although using 
a different methodology, also supports the Mayers model. The papers of Chang et al. (2004), Graham and Harvey (2001) and Bancel and Mittoo (2004), although they do not test the Mayers' theory directly, establish a link between issuing convertible bonds and the existence of investment opportunities.

We test the relevance of the sequential strategy using convertible bonds on the Western European market. We focus on European firms because most previous empirical studies have been conducted on the US market. Following Bancel and Mittoo (2004), we believe that Europe is worth investigating since European and US markets have different characteristics. The first is much more recent. Further, convertibles issued in Europe and in the US have different characteristics and the regulatory environment is different. For instance, differences in corporate tax rates and the levels of interest and dividends rates between Europe and USA have an effect on the cash flow advantage (Asquith and Mullins, 1991) and on the yield advantage (Constantinides and Grundy, 1987) that have an impact on the call strategy of the bond on the voluntary conversion strategy of investors. Dutordoir and Van de Gucht (2004) show that European convertible bonds are more debt-like than US convertible bonds. In the US, most convertibles are issued via private placement, which is not the case in Europe (Bancel et al., 2009). Both the characteristic of the issuer and the design of the convertible bonds suggest that the company motivations for issuing convertible bonds are not the same in the US and the Western European markets (see for example the surveys of Billingsley and Smith, 1996, Graham and Harvey, 2001 and Bancel and Mittoo, 2004). Regarding the characteristic of the convertible bonds issuers, existing literature provide evidence supporting that the European and US convertible bonds issuers are not similar. According to Noddings et al. (2001) and Dutordoir and Van de Gucht (2004), European convertible bonds issuers are large, financially healthy and mature firms which is in contradiction with the US convertible bonds issuers which are small, risky and high-growth companies (see Lewis et al. 2003). This difference seems particularly important in the perspective of testing the sequential financing theory of Mayers (1998). In effect, sequential financing is a way to control overinvestment and this problem is probably more relevant for mature firms that have less investment opportunities than high growth companies. Overall, it is interesting to investigate if these differences between European and US convertible bonds issuers are reflected in the sequential financing strategy.

The main methodological issue to test the Mayers' model is to compare the investment and financing activities generated by the callable convertible bonds strategy with an appropriate benchmark. In this paper, we will make essentially two different comparisons. First, in the same 
spirit as in the original paper of Mayers (1998), we will compare the investment and financing activities around the date at which companies have called theirs bonds to those of non-calling companies, which operate in the same industry. Then, following Alderson et al. (2006) we compare the investment and financing activities of the firms that called their convertibles bonds in-the-money to those that called them out-of-the-money. As in all previous empirical papers, we use industry means and medians as proxies for normal behavior. Furthermore, unlike the previous papers, our study uses difference-in-differences models to identify whether the investment and financing activities are different between companies using the convertible bonds strategy and the control group. The objective is to take into account the underlying trend in investment financing strategy, but we think that difference-in-differences is a more suitable method than those implemented in the previous papers. More specifically, it is helpful in addressing possible evaluation biases due to the effects of unobservable variables, which could be driving the difference in investment and financing activities between the convertible bonds strategy and the control group ${ }^{1}$. In line with the sequential financing hypothesis, we predict that the firms that called their bonds will have more investment financing activities around the call date than non-calling firms and firms that called their bonds in-the-money will invest more than those that called them out-of-the-money.

We use a sample of 277 callable convertible bonds issued by non-financial firms in Western Europe between 1994 and 2009, comprising 161 called bonds and 116 non-called bonds. We find evidence only partially in line with the sequential financing hypothesis of Mayers (1998). For the calling firms ${ }^{2}$, we find positive changes in capital expenditure at call dates that are greater than those of the non-calling firms. But in contrast with Mayers' theory and like Alderson et al. (2006), we do not find any significant difference in investment patterns between in-the-money and out-of-the-money calling firms at the call dates which would be attributable to the call decision.

The paper is organized as follows: Section 2 presents the main theoretical and empirical findings relative to the sequential financing. Section 3 presents the hypotheses with their justifications. Section 4 provides details on the data, the methodology and the results. In a

\footnotetext{
${ }^{1}$ See Roberts and Whited (2012) for a review of the difference-in-differences applications in finance.

2 "Calling firms" refer to issuers that exercise their call provision. "Non-calling" firms are those that do not early called their bonds.
} 
conclusion, we discuss the contributions of our study compared with previous empirical studies on sequential financing strategy.

\section{Literature review}

Mayers' theory considers a firm in a two-world period that initially presents an immediate profitable investment project and an investment option that matures at the start of the second period. Uncertainty is related to the second project (option). The convertible is constructed so that it is out-of-the-money at issue date and becomes in-the-money if the investment option is profitable. If the conversion option alone makes it possible to draw a parallel between the flexibility of financing and investment, the call feature reinforces this contribution of flexibility and facilitates the financing of the real investment option. By providing additional equity, conversion will create new debt capacity and therefore additional financing to invest, avoiding the company having to issue new financing and thus economizing issue costs. Furthermore, if, at the issuing date, the maturity date of the investment option is unknown, issuers may use the call provision included in the contract to ensure investment timing flexibility.

Few studies test Mayers (1998) sequential financing theory. The empirical findings relative to this theory include those provided by Mayers (1998), Chang et al. (2004), Korkeamaki and Moore (2004), Alderson et al. (2006) and King and Mauer (2014). Using matching procedures to compare investment and financing activities of the firms that called their bonds with those of their respective industries around the year the conversion was forced, Mayers (1998) and King and Mauer (2014) find strong support for the sequential financing hypothesis. Since the forced conversion is supposed to take place only if the investment option is valuable, it is expected that it will be followed by significant financing and investment activities. They record positive changes in the investment and financing activities for calling firms that are significantly different from those of their respective industries during the years of conversion but also for the next two years. By analyzing the convertible bonds call policy, King and Mauer (2014) also find that issuers which seized growth opportunities are more often those which forced the conversion. The fact that companies with important growth opportunities will issue callable convertible in order to force conversion when these opportunities become profitable is consistent with the sequential financing hypothesis. 
Korkeamaki and Moore (2004) also investigate the investment activities of convertible bond issuers, but around the issuance date rather than the call dates. They find increasing capital expenditure from the issuance date to the next five years for firms with high growth and volatility compared with those facing low growth and volatility. For the latter, the changes in capital expenditure become negative two years after the issuance of the convertible bonds. In short, their paper shows that the sequential financing strategy is relevant for high growth and more volatile companies.

Chang et al. (2004) also show interest in convertible bonds for sequential funding. Their approach differs from other studies since the authors study the market reaction at the issue date. If the convertible bonds are used to implement a sequential financing strategy then the market should respond positively to the announcement, since the choice of sequential financing implies the existence of growth opportunities that explains the need to raise funds. This positive reaction will be more significant for companies that have focused activities since a sequential financing strategy with convertible is generally useful when there is a positive correlation between the firm's various projects (see Mayers, 1998). They observe, in fact, that on the Taiwanese market, market reaction is positive for less diversified firms and negative for diversified firms. Furthermore, the authors analyze the new securities issuance level after the convertible bond issuance and before the call and observe a very low level of investing and financing activities during this period. This demonstrates that, in line with sequential financing theory, companies use convertible bonds to limit the costs related to accession to the financial markets when they have investment options at issuance.

However, Alderson et al. (2006) obtain results that challenge the sequential financial theory. In effect, conversion-forcing firms exhibit, as expected by Mayer's theory, an increase in both capital expenditure and debt financing around the year of the convertible bond call. Nevertheless, as the phenomenon is observed for in the money but also for out of the money calls, the staged financing hypothesis is rejected.

\section{Hypotheses}

We test the main empirical consequence of Mayers' theory. The test of this theory generates two problems: (1) which are the firms that implement sequential financing strategy? and (2) to which companies should they be compared? Firstly, when companies issue CB they 
do not publicly indicate whether the objective of the issue is to implement a sequential financing strategy. Therefore, for each hypothesis we compare investment and financing activities of a first group of the firms that potentially implement sequential financing strategy to those of a second group for which the call or the redemption decisions are less related to sequential financing. Secondly, the characteristics and the motivations of the $\mathrm{CB}$ issuers are different from non-CB issuers. As the difference-in-difference method assumes that the treated and control group should be as similar as possible, we find more appropriate to compare the financing and investment activities of these firms to those of companies having at least called or redeemed their CB. The hypotheses are as follow:

H1a) (Mayers, 1998): Investment and financing activities around the date on which companies have called their bonds should be more important than these activities around the maturity date of non-calling companies, which operate in the same industry. In diagram 1 we compare (a) + (b) with (c) $+($ d).

This hypothesis tests if the exercise of the call option (whatever the purpose of this exercise) allows companies to develop their investment and financing activities compared to companies that choose not to exercise their call option. We make this comparison because we cannot identify if the company objective is to implement a sequential financing strategy or not. For this, and because the maturity of the investment option is subject to uncertainty, we can predict that firms that exercise the call option of theirs $\mathrm{CB}$ are much likely to achieve the sequential financing than the firms that do not early call their bonds. The hypothesis H1a supposes that ITM calling firms are close to OTM calling firms but the two are quite different from non-calling firms. In sequential financing setting, ITM call options signal valuable investment option while OTM call options are associated with unprofitable investment option. This is the case when the investors are well informed. In situation of asymmetric information, there is a possibility that a profitable investment option is associated with OTM call option and vice versa. Managers with positive private information about their company, could decide to call back their OTM CB in order to preserve the wealth of the existing shareholders or to signal this private information to investors (see for example Cowan et al., 1993).

H1b) (Mayers, 1998): Investment and financing activities around the date on which companies have called their in-the-money bonds (forced conversion) should be more important than those of companies that are subject to voluntary conversion, which operate in the same industry. In diagram 1 we compare (a) with (c). 
The two groups we compare here potentially have profitable investment option (ITM call/conversion option) but the exercise of the early call provision is more consistent with the sequential financing theory. Hence, we expect that the investment and financing activities will be more important for the firms that forced the conversion of their CB. In Mayers (1998) model, non-callable $\mathrm{CB}$ can achieve the sequential financing when the maturity of the investment option is known. So, we can consider that when the company chooses callable $\mathrm{CB}$, there is an uncertainty relative to the maturity of the investment option. In consequence, we predict that the voluntary conversion at maturity of callable CB does not serve to staged financing. The call delay of the ITM callable CB until their maturity can be explained instead by several theories. For example, Harris and Raviv (1985) argues that managers with favorable private information prefer to delay the call which signals that the managers are confident that the conversion will take place at maturity. This theory explains the negative decline in issuers' stock price at the announcements of ITM CB calls. Other theories can also explain the decision of the firms not to force the conversion of their bonds: the transaction costs (Ingersoll, 1977), the financial distress costs (Jaffee and Shleifer,1990), the cash flow advantage theory (Constantinides and Grundy, 1986).

H2) (Alderson et al., 2006): Investment and financing activities around the in-the-money call dates should be more important than those of out-of-the-money calls for firms that operate in the same industry. In diagram 1, we compare (a) with (b).

Here, in the two comparison groups the companies exercise the call provision. But under market efficiency hypothesis, only ITM CB calls can be interpreted as an exercise of the ITM investment option. We then predict more important investment and financing activities for these firms. However, in presence of asymmetric information, the managers can decide to call back their OTM CB if they have positive private information. In that case, the difference between the investment activities of the two groups is expected to be less important.

In the three hypotheses, we also predict larger financing activities because there is a possibility that for some firms the cash redemption economies (due to the conversion) are not sufficient to face the investment needs. As expected by Mayers (1998), in this situation, firms will increase their financing activities to face this additional need. Admittedly, the problem of financing cost arises but for these firms, the improvement of the capital structure following the conversion help to issue the new debt at lower cost. 
Hypothesis (H1b) is closer to the Mayers' theory because if the call is in the money, it should signal profitable investment opportunities compared to companies where bondholders choose to convert their bonds in the money. This hypothesis emphasis on the flexibility offered by the call option associated to the convertible bond because at the issuing time of callable convertible bond, the maturity of the investment option is not known. Finally, following Alderson et al. (2006), what distinguishes the staged financing hypothesis from other theories presented above is the "prediction that firms will increase their investment and financing activities after in the money (conversion forcing) convertible calls, but not after out of the money convertible calls (which do not lead to conversion)".

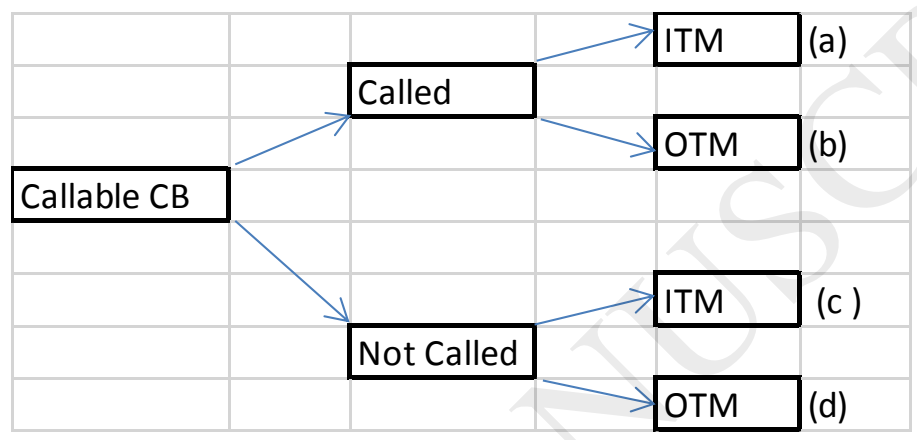

Diagram 1. Different scenarios of convertible bond options

\section{Empirical Studies}

We present in this section the methodology used to test the sequential investing and financing hypothesis of Mayers (1998), the sampling procedure and the results of our empirical analysis.

\subsection{Methodology}

Following the methodology of Alderson et al. (2006), investment and financing activities are analyzed from two years before the event dates (call dates or conversion option at maturity) to two years after these events (the window is therefore $[-2 ;+2], 0$ being the year of call date or maturity date). On this window, we reveal the differences in investment and financing activities between the two groups of companies as explained in hypotheses H1a, H1b, H2. Whatever the hypothesis, the two subsamples are industry-matched. The matching 
procedure is as follow: the investment and financing activities around the exercise of the call of each company in the first group is compared to the same activities during the same period for firms in the second group operating in the same industry. We use the 4-digit S\&P GICS classification for the matching procedure except for the comparison made in $\mathrm{H}_{1} \mathrm{~b}^{3}$. As previous studies, we compute the investment and financing activities levels and variations two years before and after the event. This choice allows us to identify potential progressive investment and financing activities which can start prior the call or maturity dates of the convertibles. However, we focus mainly in what happens during the year of the convertible bonds call. We test eventual differences between the different subsamples using two statistical tests (Wilcoxon-Mann-Whitney for the differences in mean and the Mood's median tests) and the difference-in-differences methodology introduced by Card and Krueger (1994). The differencein-differences model serves to identify whether the company decision to call has a significant impact on the financing and investment activity of the firms. The treatment effects are investigated from year -1 to year 0 , year +1 and year +2 . In effect, the classical methodology allows to detect if there are significant differences in the level or in the change of the investment and financing strategy between the two group of firms during the same year. But they fail to test if the evolution of the strategy from one year to another is significantly different between the two groups. That what the difference in difference methodology allows to do.

\subsection{Sample constitution and data description}

We describe here the sampling procedure and the data used to investigate the sequential financing hypothesis of Mayers (1998) on Western European markets.

\subsubsection{Sample}

Our study aims to analyze the investment and financing activities of companies around call dates of convertible bonds in Western Europe. All the data are extracted from the Bloomberg database. Our initial sample consists of 454 callable convertible bonds over the

\footnotetext{
${ }^{3}$ We use instead the 2-digit S\&P GICS classification because the number of observations of the subsample of the voluntary conversions is not sufficient to implement properly the matching procedure.
} 
period 1994 to 2009 in Western Europe. We excluded financial firms. We then proceeded to eliminations based on the ability to obtain the essential data for this study, namely the call announcement dates according to the subsample as well as the information relative to the investment and financing activities of issuers. After this first sampling procedure, we obtain a subsample of 161 convertible bonds called before the maturity and 116 convertible bonds redeemed at their maturity. A second sampling procedure is conducted to obtain the subsample of in the money and out of the money calls and that of the forced and voluntary conversions. For some convertibles, we are unable to identify whether the call (conversion) option was in or out of the money when the call or redemption occurred. This is due to the unavailability of some bond characteristics such as conversion ratio. Finally, we could identify the moneyness of 108 called bonds (57 when the call option was in the money and 51 when this option was out of the money) and 87 not-called bonds ( 42 when the conversion option was in the money and 45 when this option was out of the money). Moreover, the call (conversion) option is in the money if the conversion value (stock price * conversion ratio) exceeds the effective call price or redemption price. Diagram 2 presents the various subsamples used to test hypothesis H1a, $\mathrm{H} 1 \mathrm{~b}$ and H2 (coITM: conversion option was in the money, CoOTM conversion option was out of the money, CaITM: call option was in the money, CaOTM call option was out of the money).

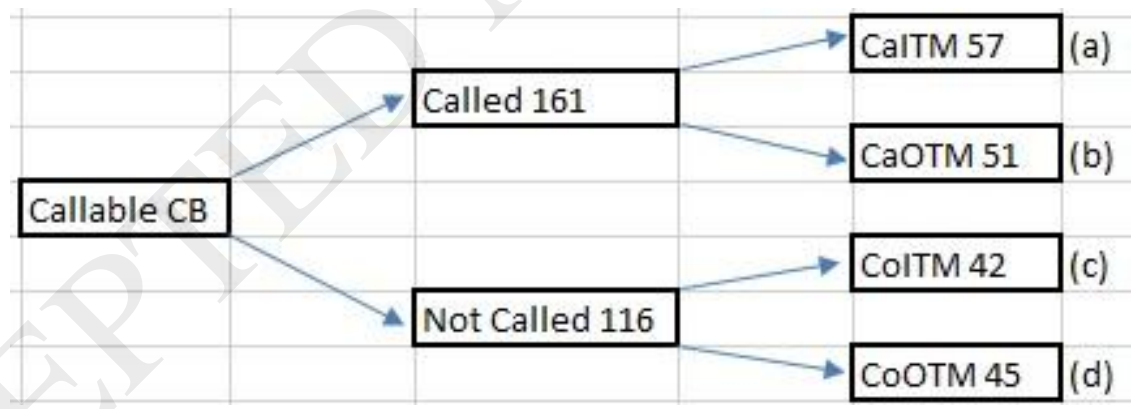

Diagram 2- Sample Structure

Tables 1 and 2 provide descriptive statistics on the various subsamples (Calling versus Noncalling, forced versus voluntary conversions, in-the-money call versus out-the-money call).

As shown in Table 1, the English, French and Dutch issuers are the most important in Western Europe with respectively 34\%, 23\%, and 14\% of issues. We can see also that the majority of issuers $(58 \%)$ exercise the call option confirming the importance of the flexibility offered by this clause for the issuer. Note also that a significant proportion of calls occurs in United Kingdom, France and the Netherlands. We observe quite different behaviors between 
the Netherlands and the UK: in the first country, calls are mostly out of the money, while the opposite is true in the UK. In France, the twos are almost equilibrated (17 versus 21).

In Table 2 we can observe that most firms in our sample operate in Materials (13.72\%) and Technology Hardware \& Equipment industries (10.47\%). In these sectors, the call is exercised in the great majority of cases in contrast with the capital good industry. The number of forced compared to voluntary conversions are similar (or the sample is too small to lead conclusion) except for the technology hardware and equipment sector where forced conversions are dominant (8 against 1 ). Finally, at the notable exception of the transportation industry, there is no big difference between the number of calls exercised in and out the money. 
Table 1: Distribution of convertible bonds in Western Europe by country

\begin{tabular}{|c|c|c|c|c|c|c|c|c|c|}
\hline \multirow{2}{*}{ Country } & \multicolumn{3}{|c|}{ Calling vs Non-calling } & \multicolumn{3}{|c|}{ Forced vs Voluntary conversions } & \multicolumn{3}{|c|}{ ITM vs OTM Calls } \\
\hline & 'alled & Non-called & Total & Forced & Voluntary & Total & ITM & OTM & Total \\
\hline Austria & $01(00.62)$ & $00(00.00)$ & $(0$ & $00(00.00)$ & $00(00.00)$ & $00(00.00)$ & $00(00.00)$ & $01(01.96)$ & $01(00.9$ \\
\hline Belgium & $00(00.00)$ & $02(01.72)$ & $(00.72)$ & $00(00.00)$ & $00(00.00)$ & $00(00.00)$ & $00(00.00)$ & $00(00.00)$ & $00(00.0$ \\
\hline Denmark & $(01.24)$ & $00(00.00)$ & $02(00.72)$ & $00(00.00)$ & $01(02.38)$ & $01(01.01)$ & $00(00.00)$ & $00(00.00)$ & $00(00.0$ \\
\hline Dutch & $24(14.91)$ & $15(12.93)$ & $39(14.08)$ & $04(07.02)$ & $02(04.76)$ & $06(06.06)$ & $04(07.02)$ & $11(21.57)$ & $15(13.8$ \\
\hline Finland & $04(02.48)$ & $01(00.86)$ & $05(01.81)$ & $00(00.00)$ & $00(00.00)$ & $00(00.00)$ & $00(00.00)$ & $04(07.84)$ & $04(03.70$ \\
\hline France & $46(28.57)$ & $19(16.38)$ & $65(23.47)$ & $17(29.82)$ & $11(26.19)$ & $28(28.28)$ & $17(29.82)$ & $21(41.18)$ & $38(35.19$ \\
\hline Germany & $04(02.48)$ & $04(03.45)$ & $08(02.89)$ & $03(05$ & $00(00.00)$ & $03(03.03)$ & $03(05.26)$ & $00(00.00)$ & $03(02.78$ \\
\hline Greece & $00(00.00)$ & 04 & 0 & ) & 02 & 02 & $0.00)$ & 00 & 00 \\
\hline Ireland & $03(01.86)$ & $01(00.86)$ & & 0210 & 00 & 02 (c) & $02(03.51)$ & 01 & 00 (02.1 \\
\hline Italy & $01(00.62)$ & $06(05.17)$ & $07(02$ & $00(00$. & $00(00$ & $00(00.00)$ & $00(00.00)$ & $00(00.00)$ & $00(00.0$ \\
\hline Luxembour & $15(09.32)$ & $04(03.45)$ & $19(06.86)$ & $03(05$ & $03(0$ & $06(06.06)$ & $03(05.26)$ & $04(07.84)$ & $07(06.4$ \\
\hline Norway & $02(01.24)$ & 03 (02.59) & $05(01.81)$ & $00(00.00)$ & $03(07.14)$ & $03(03.03)$ & $00(00.00)$ & $01(01.96)$ & $01(00.93$ \\
\hline Portugal & $00(00.00)$ & $01(00.86)$ & $01(00.36)$ & $00(00.00)$ & $00(00.00)$ & $00(00.00)$ & $00(00.00)$ & $00(00.00)$ & $00(00.00$ \\
\hline Spain & $01(00.62)$ & $04(03.45)$ & $05(01.81)$ & $00(00.00)$ & $03(07.14)$ & $03(03.03)$ & $00(00.00)$ & $00(00.00)$ & $00(00.0$ \\
\hline Sweden & $00(00.00)$ & $05(04.31)$ & $05(01.81)$ & $00(00.00)$ & $01(02.38)$ & $01(01.01)$ & $00(00.00)$ & $00(00.00)$ & $00(00.0$ \\
\hline Switzerland & $08(04.97)$ & $03(02.59)$ & $11(03.97)$ & $00(00.00)$ & $00(00.00)$ & $00(00.00)$ & $00(00.00)$ & $02(03.92)$ & $02(01.85$ \\
\hline UK & $50(31.06)$ & 44 (37.93) & $94(3$ & $28(49.12)$ & $16(38.10)$ & 44 & $28(49.12)$ & $06(11.76)$ & $34(3$ \\
\hline Total & $161(100)$ & $116(100)$ & 277 (100) & $57(100)$ & $2(100)$ & $99(100)$ & $57(100)$ & $51(100)$ & 108 \\
\hline
\end{tabular}

This table presents the number and relative size of Calling vs non-calling Convertible Bonds, Forced vs Voluntary and In The Money vs Out of The Money calls, issued by non-financial companies. "Calling Firms" refers to the subsample of convertible bonds called before their maturity and "non-calling Firms" refers to the subsample of callable convertible bonds redeemed at maturity. 
Table 2: Firms' industries based on S\&P GICS classification

\begin{tabular}{|c|c|c|c|c|c|c|c|c|c|}
\hline \multirow[b]{2}{*}{ Industry } & \multicolumn{3}{|c|}{ Calling vs non-calling } & \multicolumn{3}{|c|}{ Forced vs Voluntary conversions } & \multicolumn{3}{|c|}{ ITM vs OTM Calls } \\
\hline & Called & Non-called & Total & Forced & Voluntary & Total & ITM & OTM & Total \\
\hline Automobiles \& Components & $06(03.73)$ & $02(01.72)$ & $08(02.89)$ & $03(05.26)$ & $01(02.38)$ & $04(04.04)$ & $03(05.26)$ & $02(03.92)$ & $05(04.63)$ \\
\hline Capital Goods & $05(03.11)$ & $22(18.97)$ & $27(09.75)$ & $08(14.04)$ & 07 (16.67) & $15(15.15)$ & $08(14.04)$ & $11(21.57)$ & $19(17.59)$ \\
\hline Commercial \& Professional Services & $12(07.45)$ & $04(03.45)$ & $16(05.78)$ & $00(00.00)$ & $02(04.76)$ & $02(02.02)$ & $00(00.00)$ & $00(00.00)$ & $00(00.00)$ \\
\hline Consumer Durables \& Apparel & $06(03.73)$ & $10(08.62)$ & $16(05.78)$ & $02(03.51)$ & $03(07.14)$ & $05(05.05)$ & $02(03.51)$ & $00(00.00)$ & $02(01.85)$ \\
\hline Consumer Services & $02(01.24)$ & $04(03.45)$ & $06(02.17)$ & $01(01.75)$ & $02(04.76)$ & $03(03.03)$ & $01(01.75)$ & $01(01.96)$ & $02(01.85)$ \\
\hline Energy & $08(04.97)$ & $05(04.31)$ & $13(04.69)$ & $00(00.00)$ & $01(02.38)$ & $01(01.01)$ & $00(00.00)$ & $06(11.76)$ & $06(05.56)$ \\
\hline Food \& Staples Retailing & $18(11.18)$ & $03(02.59)$ & $21(07.58)$ & $03(05.26)$ & $01(02.38)$ & $04(04.04)$ & $03(05.26)$ & $02(03.92)$ & $05(04.63)$ \\
\hline Food, Beverage \& Tobacco & $03(01.86)$ & $08(06.90)$ & $11(03.97)$ & $05(08.77)$ & $05(11.90)$ & $10(10.10)$ & $05(08.77)$ & $04(07.84)$ & $09(08.33)$ \\
\hline Health Care Equipment \& Service & $01(00.62)$ & $08(06.90)$ & $09(03.25)$ & $03(05.26)$ & $03(07.14)$ & $06(06.06)$ & $03(05.26)$ & $01(01.96)$ & $04(03.70)$ \\
\hline Household \& Personal Products & $01(00.62)$ & $00(00.00)$ & $01(00.36)$ & $00(00.00)$ & $00(00.00)$ & $00(00.00)$ & $00(00.00)$ & $01(01.96)$ & $01(00.93)$ \\
\hline Materials & $29(18.01)$ & 09 (07.76) & $38(13.72)$ & $05(08.77)$ & $02(04.76)$ & $07(07.07)$ & $05(08.77)$ & $04(07.84)$ & $09(08.33)$ \\
\hline Media & $10(06.21)$ & $04(03.45)$ & $14(05.05)$ & $03(05.26)$ & $02(04.76)$ & $05(05.05)$ & $03(05.26)$ & $00(00.00)$ & $03(02.78)$ \\
\hline Pharmaceuticals, Biotechnology \& Life Sciences & $06(03.73)$ & $02(01.72)$ & $08(02.89)$ & $00(00.00)$ & $01(02.38)$ & $01(01.01)$ & $00(00.00)$ & $01(01.96)$ & $01(00.93)$ \\
\hline Retailing & $07(04.35)$ & $10(08.62)$ & $17(06.14)$ & $04(07.02)$ & $04(09.52)$ & $08(08.08)$ & $04(07.02)$ & $00(00.00)$ & $04(03.70)$ \\
\hline Software \& Services & $03(01.86)$ & $05(04.31)$ & $08(02.89)$ & $00(00.00)$ & $01(02.38)$ & $01(01.01)$ & $00(00.00)$ & $03(05.88)$ & $03(02.78)$ \\
\hline Technology Hardware \& Equipment & $21(13.04)$ & $08(06.90)$ & $29(10.47)$ & $08(14.04)$ & $01(02.38)$ & $09(09.09)$ & $08(14.04)$ & $09(17.65)$ & $17(15.74)$ \\
\hline Telecommunication Services & $04(02.48)$ & $05(04.31)$ & $09(03.25)$ & $02(03.51)$ & $02(04.76)$ & $04(04.04)$ & $02(03.51)$ & $02(03.92)$ & $04(03.70)$ \\
\hline Transportation & $09(05.59)$ & $05(04.31)$ & $14(05.05)$ & $07(12.28)$ & $04(09.52)$ & $11(11.11)$ & $07(12.28)$ & $02(03.92)$ & $09(08.33)$ \\
\hline Utilities & $10(06.21)$ & $02(01.72)$ & $12(04.33)$ & $03(05.26)$ & $00(00.00)$ & $03(03.03)$ & $03(05.26)$ & $02(03.92)$ & $05(04.63)$ \\
\hline Total & $161(100)$ & $116(100)$ & $277(100)$ & $57(100)$ & $42(100)$ & $99(100)$ & $57(100)$ & $51(100)$ & $108(100)$ \\
\hline
\end{tabular}

This table presents the classification of convertible bonds according to their issuers' industries affiliation using the 4-digit S\&P GICS classification 


\subsubsection{Variables}

We measure the investment activity by a firm's capital expenditures around the call dates. Two sources of financing are analyzed to account for financing activity: issuance of new long-term debt and new equity. Like Alderson et al. (2006) and King and Mauer (2014), we scaled the investment and financing activities of year $t$ by the total assets of the year $t-1$. For both investment and financing activities, we also compute the changes relative to the previous year.

The size of the issuer (FIRM SIZE) is obtained by the natural logarithm of the total assets. A firm's leverage is measured by the variable (LEVERAGE) which represents the longterm debt divided by the total assets. The amount of the issue is given by the variable (ISSUE $S I Z E$ ) that is the total amount of the issue divided by the total assets. The profitability of growth opportunities is given by the variable $(M T B V)$ which is the market capitalization divided by the book value of common equity. These variables are calculated at various dates (at the fiscal year immediately preceding the issuance date and at the fiscal year immediately following the call dates, etc.). All data are obtained from the Bloomberg database.

Table 3 shows that at each date, calling-firms (panel A) and firms forcing conversion (panel B) are significantly larger than non-calling firms. This may be surprising because usually small companies need more flexible financing to deal with uncertainty of their growth opportunities. Firms exercising in or out of the money (panel C) have similar size. Issue size is significantly higher for calling (panel A) compared to non-calling firms and calling out of the money (panel C) firms compared to calling in the money firms.

At the call date, calling firms are more leveraged than non-calling firms (panel A) are, but as expected from the sequential investing theory, the leverage is lower in the case of in the money call (panel B).

In terms of market to book ratio (MTBV), calling firms have significantly less growth opportunities than non-calling firms do at the exercise date (panel A). Firms that exercise out of the money call have significantly more growth opportunities at issuance date and previous year than those that exercise in the money call (panel B). This can support the idea that the level of informational asymmetry is more important for these companies. 


\subsection{Results}

We present successively the results of our tests of the sequential financing hypothesis. Firstly, we present the results of the test of comparison of investment and financing activities for calling versus non-calling firms. Calling decision indicates the possible existence of investment opportunities that should be associated, according to Mayers (1998), with higher investing/financing activities (H1a). Secondly, we present the results relative to the importance of the call provision for the flexibility of the sequential financing strategy by comparing the investment and financing activities of firms forcing conversion (in the money calls) with investment and financing activities of firms with voluntary conversions (H1b). Thirdly, following $\mathrm{H} 2$, investment and financing activities should be more important when the call are exercised in the money (presence of investment opportunity) versus out of the money.

\subsubsection{Calling versus non calling firms (H1a)}

We test in this section the sequential financing theory by comparing financial activities of calling and non-calling firms. Table 4 shows investment and financing activities (matched with median industries) for the two groups of firms.

Firstly, concerning the investment activity (panel A of table 4), we observe significant higher capital expenditures by total assets for calling issuers than those obtained in the noncalling group before and after the call date. In terms of investment changes, we notice a positive increase in investment the year of the call and a positive and significant increase the year after the call compared to non-calling firms. However, the difference-in-differences model fails to confirm that this result is due to the call date. These results are therefore only partially in line with the sequential financial hypothesis of Mayers (1998). Exercising the call can be explained by investing reasons but could also have other reasons (in particular in the case of out of the money calls).

Regarding financing activities, the results appear contrasted for equity and debt financing. Following the difference in difference test, exercising the call has a significant positive effect on the amount of new equity issuances in exercise year and the following one (panel B of table 4). In contrast, and contrary to the sequential financing hypothesis, the amount 
and variation of debt in years after the exercise of the option is negatively impacted by the exercise choice (see the DID statistics).

\subsubsection{Forced versus voluntary conversion (H1b)}

Table 5 exhibits the investment and financing activities of issuers around the call exercise date for firms forcing conversion (Forced in the table) compared to firms where investors voluntary exercise their conversion option at maturity (Voluntary in the table).

Table 5 Panel A exhibits capital expenditures and changes in capital expenditures (on the right). The results indicate that there is no significant difference (in level or in \%) in the investment strategies between the two groups of firms. Results are therefore not in line with the sequential financing theory explanation. More specifically, the flexibility offered by the call does not seem to be used by companies to solve their investment financing problems.

In Table 5 Panel B we observe that the level of new equity issuances of forced conversion firms is lower before the conversion and higher after the conversion compared to voluntary conversion firms, but the difference in difference statistic is not significant. There is a significant increase in equity issuance at the calling date (but in this case, also the difference in difference statistic is not significant).

Table 5 (Panel C) also shows that the increase in debt financing is significantly (at time 0 and +2 ) lower after the call for forced conversion firms compared to voluntary conversion firms. This result contradicts the Mayers' theory.

In short, the investment and financing decisions does not seem to be driven by the voluntary conversion in contrast with the sequential investment theory. 
Table 3: Characteristic differences of firms between samples

\begin{tabular}{|c|c|c|c|c|c|c|c|c|c|c|c|c|}
\hline \multirow{2}{*}{ Period } & \multicolumn{3}{|c|}{ FIRM SIZE } & \multicolumn{3}{|c|}{ LEVERAGE } & \multicolumn{3}{|c|}{ MTBV } & \multicolumn{3}{|c|}{ ISSUE SIZE } \\
\hline & $1^{\text {st }}$ group & $2^{\text {nd }}$ group & z stat & $1^{\text {st }}$ group & $2^{\text {nd }}$ group & z stat & $1^{\text {st }}$ group & $2^{\text {nd }}$ group & z stat & $1^{\text {st }}$ group & $2^{\text {nd }}$ group & z stat \\
\hline \multicolumn{13}{|c|}{ Panel A: Calling versus Non-calling CB } \\
\hline Issuance Date-1 & $7.99(8.11)$ & $6.66(6.92)$ & $-4.40 * * *$ & $0.18(0.15)$ & $0.20(0.17)$ & 1.06 & $2.68(1.71)$ & $3.97(1.77)$ & -0.47 & & & \\
\hline Issuance Date & $8.16(8.33)$ & $6.87(7.10)$ & $-4.51 * * *$ & $0.24(0.21)$ & $0.24(0.21)$ & 0.30 & $3.74(1.88)$ & $2.52(1.63)$ & -1.30 & $0.68(0.09)$ & $0.09(0.07)$ & $-2.53 * *$ \\
\hline Exercise Date & $8.41(8.43)$ & $6.86(7.17)$ & $-5.19 * * *$ & $0.20(0.18)$ & $0.17(0.15)$ & $-1.97 * *$ & $2.46(2.02)$ & $2.78(1.57)$ & $-2.06 * *$ & & & \\
\hline Exercise Date +1 & $8.48(8.51)$ & $6.73(6.80)$ & $-5.78 * * *$ & $0.20(0.18)$ & $0.17(0.15)$ & -1.36 & $2.68(2.13)$ & $2.80(1.77)$ & $-1.79 *$ & & & \\
\hline \multicolumn{13}{|c|}{ Panel B: Forced versus Voluntary conversions } \\
\hline Issuance Date-1 & $8.33(8.43)$ & $6.34(7.04)$ & $-3.69 * * *$ & $0.17(0.14)$ & $0.19(0.13)$ & -0.29 & $1.62(1.55)$ & $1.82(1.53)$ & 0.08 & & & \\
\hline Issuance Date & $8.38(8.51)$ & $6.51(7.10)$ & $-3.83 * * *$ & $0.24(0.20)$ & $0.22(0.18)$ & -0.41 & $2.11(1.74)$ & $1.64(1.37)$ & -0.86 & $0.13(0.07)$ & $0.10(0.10)$ & 0.13 \\
\hline Exercise Date & $8.29(8.51)$ & $6.99(7.38)$ & $-2.99 * * *$ & $0.19(0.15)$ & $0.18(0.18)$ & -0.02 & $2.46(2.00)$ & $2.70(1.72)$ & -0.85 & & & \\
\hline Exercise Date +1 & $8.38(8.72)$ & $689(7.43)$ & $-3.35 * * *$ & $0.19(0.16)$ & $0.18(0.16)$ & -0.26 & $2.83(2.01)$ & $3.12(2.30)$ & 0.11 & & & \\
\hline \multicolumn{13}{|c|}{ Panel C: In the money versus Out of the money Call option } \\
\hline Issuance Date-1 & $8.33(8.43)$ & $8.12(8.67)$ & -0.45 & $0.17(0.14)$ & $0.17(0.15)$ & 0.64 & $1.62(1.55)$ & $3.06(2.11)$ & $2.66 * * *$ & & & \\
\hline Issuance Date & $8.38(8.51)$ & $8.31(8.77)$ & -0.10 & $0.24(0.20)$ & $0.24(0.22)$ & 0.45 & $2.11(1.74)$ & $3.67(2.45)$ & $1.82 *$ & $0.13(0.07)$ & $0.25(0.12)$ & $1.98^{* *}$ \\
\hline Call Date & $8.29(8.51)$ & $8.62(8.74)$ & 0.92 & $0.19(0.15)$ & $0.22(0.19)$ & $1.72 *$ & $2.46(2.00)$ & $2.27(2.03)$ & 0.14 & & & \\
\hline Call Date +1 & $8.38(8.72)$ & $8.67(8.77)$ & 0.80 & $0.19(0.16)$ & $0.20(0.19)$ & 0.78 & $2.83(2.01)$ & $2.47(2.20)$ & 0.45 & & & \\
\hline
\end{tabular}

This table shows the means and medians (in parentheses) for some characteristics of calling and non-calling firms, forced versus voluntary conversion and in the money versus out of the money call option around the issuance and the exercise dates of their convertible bonds between January 1994 and December 2009 on the Western European market. FIRM SIZE is the natural logarithm of the firm's total assets. LEVERAGE is the long-term debt divided by the total assets. MTBV is the market capitalization divided by the book value of common equity. ISSUE SIZE is the total amount of convertible bond issued divided by the total assets. The columns " $z$ stat" indicate for each characteristic the $\mathrm{z}$ value and the level of significance of the difference in means for calling and non-calling firms. Wilcoxon rank-sum test (Mann-Whitney test) is used to assess this difference. *, ** and *** denote respectively the level of significance at $10 \%, 5 \%$ and $1 \%$. 
Table 4: Industry-matched investment and financing activities around convertible bonds calls (Calling versus Non-calling)

\begin{tabular}{|c|c|c|c|c|c|c|c|c|c|c|c|c|c|c|}
\hline \multirow[b]{2}{*}{ Period } & \multicolumn{7}{|c|}{ Investment and financing activities } & \multicolumn{7}{|c|}{ Changes in investment and financing activities } \\
\hline & Calling firms & Obs. & $\begin{array}{c}\text { Non-calling } \\
\text { firms }\end{array}$ & Obs. & Z stat & Chi2 & DID & Calling firms & Obs. & $\begin{array}{c}\text { Non-calling } \\
\text { firms }\end{array}$ & Obs. & Z stat & Chi2 & DID \\
\hline \multicolumn{15}{|c|}{ Panel A: Capital expenditures } \\
\hline-2 & $6.93(5.78)$ & 118 & $5,52(4,50)$ & 97 & $-0,51$ & 1,00 & - & $0.83(0.14)$ & 117 & $0,66(0,19)$ & 93 & 0,88 & 1,15 & - \\
\hline-1 & $6.51(5.67)$ & 121 & $5,70(3,98)$ & 101 & $-1,50$ & $13,37 * * *$ & - & $0.67(0.39)$ & 116 & $1,02(0,05)$ & 100 & $-1,68^{*}$ & 0,50 & - \\
\hline 0 & $6.84(5.32)$ & 128 & $5,26(3,89)$ & 108 & $-0,48$ & 0,38 & 0,001 & $0.91(0.55)$ & 121 & $0,12(0,00)$ & 102 & $-1,39$ & 1,62 & $-0,001$ \\
\hline+1 & $6.66(5.10)$ & 131 & $5,08(3,38)$ & 109 & $-1,07$ & $2,99 *$ & 0,003 & $0.38(0.18)$ & 128 & $-0,59(-0,06)$ & 106 & $-1,92^{*}$ & $4,21 * *$ & 0,002 \\
\hline+2 & $6.41(5.16)$ & 132 & $4,96(3,50)$ & 101 & $-0,68$ & $9,80 * * *$ & $-0,001$ & $0.46(0.21)$ & 131 & $0,49(0,11)$ & 100 & $-1,57$ & 2,29 & $-0,005$ \\
\hline \multicolumn{15}{|c|}{ Panel B: New equity issuances } \\
\hline-2 & $2.51(0.27)$ & 111 & $3,71(0,15)$ & 87 & $6,06 * * *$ & $19,44 * * *$ & - & $0.11(0.00)$ & 104 & $0,14(0,00)$ & 83 & $-1,78^{*}$ & $11,33^{* * *}$ & - \\
\hline-1 & $2.22(0.24)$ & 118 & $5,59(0,07)$ & 92 & $5,48 * * *$ & $39,04 * * *$ & - & $0.67(0.00)$ & 108 & $2,90(0,00)$ & 84 & $-3,96 * * *$ & $31,75^{* * *} *$ & - \\
\hline 0 & $2.97(0.36)$ & 118 & $2,48(0,06)$ & 98 & $3.13 * * *$ & $22,55^{* * *}$ & $0,024 *$ & $1.40(0.02)$ & 112 & $-1,22(0,00)$ & 88 & $-1,85^{*}$ & 0,67 & 0,009 \\
\hline+1 & $2.83(0.27)$ & 124 & $3,16(0,02)$ & 94 & $3,69 * * *$ & $15,57 * * *$ & $0,032 *$ & $0.11(0.00)$ & 114 & $0,47(0,00)$ & 92 & 0,47 & 1,51 & $-0,007$ \\
\hline+2 & $1.27(0.26)$ & 122 & $2,57(0,03)$ & 88 & $2,35 * *$ & $4,54 * *$ & 0,029 & $-0.83(0.00)$ & 121 & $0,26(0,00)$ & 83 & $-2,36^{* *}$ & $11,62 * * *$ & $-0,012$ \\
\hline \multicolumn{15}{|c|}{ Panel C: New long-term debt issuances } \\
\hline-2 & $7.93(2.65)$ & 101 & $7,18(2,49)$ & 85 & $4,34 * * *$ & $7,47 * * *$ & - & $0.39(0.00)$ & 94 & $-1,57(0,00)$ & 77 & $-1,83^{*}$ & $18,78 * * *$ & - \\
\hline-1 & $10.39(2.25)$ & 105 & $4,00(0,82)$ & 87 & 0,57 & 1,09 & - & $5.63(0.00)$ & 97 & $-1,65(0,00)$ & 82 & $-2,09 * *$ & 0,03 & - \\
\hline 0 & $7.72(3.53)$ & 117 & $5,90(1,60)$ & 93 & $2,93 * * *$ & $7,60 * * *$ & $-0,058 * * *$ & $0.62(0.00)$ & 101 & $1,51(0,00)$ & 84 & $3,26 * * *$ & $8,56^{* * *}$ & $-0,088 * * *$ \\
\hline+1 & $6.79(2.43)$ & 117 & $5,66(0,72)$ & 88 & $3,22 * * *$ & $8,76^{* * *}$ & $-0,060 * * *$ & $0.91(0.00)$ & 111 & $-1,40(0,00)$ & 86 & $-0,67$ & 2,36 & $-0,057 * *$ \\
\hline+2 & $6.79(3.86)$ & 119 & $6,28(0,72)$ & 88 & 1,51 & $6,56^{* *}$ & $-0,060 * * *$ & $1.70(0.15)$ & 112 & $1,71(0,00)$ & 81 & 0,74 & $5,24 * *$ & $-0,068 * * *$ \\
\hline
\end{tabular}

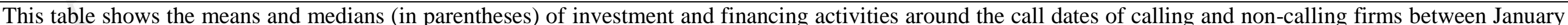

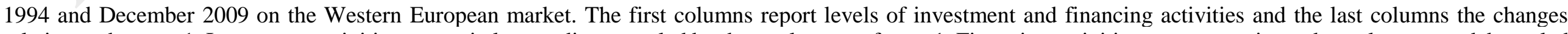

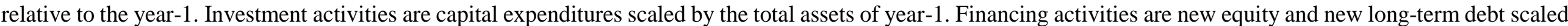

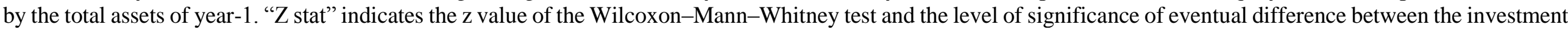

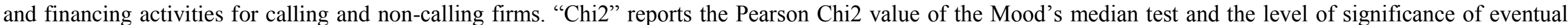

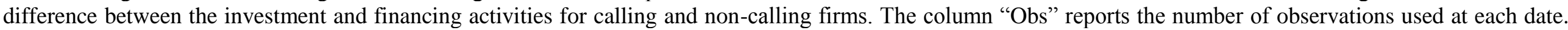

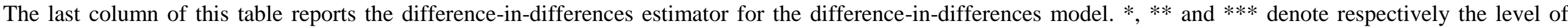
significance at $10 \%, 5 \%$ and $1 \%$. 
Table 5: Industry-matched investment and financing activities around convertible bonds calls (Forced versus Voluntary conversions)

\begin{tabular}{|c|c|c|c|c|c|c|c|c|c|c|c|c|c|c|}
\hline \multicolumn{8}{|c|}{ Investment and financing activities } & \multicolumn{7}{|c|}{ Changes in investment and financing activities } \\
\hline Period & Forced & Obs. & Voluntary & Obs. & Z stat & Chi2 & DID & Forced & Obs. & Voluntary & Obs. & Z stat & Chi2 & DID \\
\hline \multicolumn{15}{|c|}{ Panel A: Capital expenditures } \\
\hline-2 & $5.08(4.39)$ & 50 & $4,70(4,11)$ & 35 & $-0,02$ & 0,29 & - & $0.14(0.07)$ & 50 & $0,38(3,39)$ & 33 & 0,74 & 1,32 & - \\
\hline-1 & $5.57(4.78)$ & 52 & $4,51(3,99)$ & 36 & $-1,48$ & $11,11 * * *$ & - & $0.92(0.65)$ & 50 & $0,33(0,04)$ & 36 & $-2,19 * *$ & $11,60 * * *$ & - \\
\hline 0 & $6.27(5.47)$ & 54 & $5,08(4,71)$ & 38 & $-0,77$ & 0,89 & 0,001 & $1.18(0.48)$ & 52 & $0,92(0,84)$ & 35 & $-0,16$ & 1,29 & $-0,003$ \\
\hline+1 & $5.97(4.66)$ & 57 & $5,36(4,33)$ & 37 & $-0,84$ & 1,05 & $-0,005$ & $-0.06(0.06)$ & 54 & $0,23(0,23)$ & 37 & $-0,31$ & 0,50 & $-0,009$ \\
\hline+2 & $5.24(4.13)$ & 57 & $6,11(4,95)$ & 37 & 0,35 & 1,05 & $-0,019$ & $-0.13(0.13)$ & 57 & $1,21(0,07)$ & 36 & 1,06 & 0,04 & $-0,019 * * *$ \\
\hline \multicolumn{15}{|c|}{ Panel B: New equity issuance } \\
\hline-2 & $2.17(0.20)$ & 49 & $3,65(0,33)$ & 30 & $2,98 * * *$ & 2,40 & - & $-0.17(0.00)$ & 44 & $1,64(0,10)$ & 27 & 0,42 & 0,57 & - \\
\hline-1 & $1.54(0.26)$ & 52 & $1,99(1,60)$ & 30 & $2,86 * * *$ & $4,40 * *$ & - & $0.26(0.02)$ & 46 & $0,07(-0,08)$ & 26 & $-0,76$ & 1,97 & - \\
\hline 0 & $2.90(0.37)$ & 54 & $2,02(0,14)$ & 29 & $-0,61$ & 0,29 & 0,013 & $1.46(0.14)$ & 49 & $-0,57(-0,02)$ & 27 & $-2,72 * * *$ & 2,59 & 0,018 \\
\hline+1 & $2.14(0.29)$ & 51 & $1,35(0,20)$ & 30 & 0,19 & 0,90 & 0,012 & $-0.40(-0.01)$ & 50 & $-0,26(0,03)$ & 26 & 0,46 & 1,79 & $-0,003$ \\
\hline+2 & $1.61(0.27)$ & 52 & $1,17(0,57)$ & 30 & $2,30 * *$ & 1,10 & 0,009 & $-0.10(0.00)$ & 51 & $-0,49(0,07)$ & 27 & 0,66 & 1,10 & 0,002 \\
\hline \multicolumn{15}{|c|}{ Panel C: New long-term debt issuance } \\
\hline-2 & $8.66(2.33)$ & 46 & $9,30(8,60)$ & 29 & $4,74 * * *$ & $17,26^{* * *}$ & - & $0.64(0.00)$ & 44 & $3,27(3,08)$ & 29 & $2,59 * * *$ & $5,15^{* *}$ & - \\
\hline-1 & $10.06(2.46)$ & 47 & $2,79(2,47)$ & 32 & $-0,07$ & 0,41 & - & $5.25(0.00)$ & 45 & $-4,48(-3,51)$ & 29 & $-4,34 * * *$ & $26,87 * * *$ & - \\
\hline 0 & $6.48(2.42)$ & 51 & $5,65(3,79)$ & 30 & 1,18 & 0,09 & $-0,04$ & $0.23(0.00)$ & 45 & $2,32(1,54)$ & 28 & $2,34 *$ & 2,15 & $-0,118 * * *$ \\
\hline+1 & $9.23(3.14)$ & 53 & $4,59(3,52)$ & 29 & $-0,01$ & 0,00 & 0,023 & $3.69(0.18)$ & 50 & $-1,84(-1,47)$ & 28 & $-2,04 * *$ & $2,75^{*}$ & $-0,042$ \\
\hline+2 & 7.49 (3.87) & 53 & $8,75(3,23)$ & 32 & 1,33 & 1,08 & $-0,012$ & $0.32(0.61)$ & 51 & $2,84(-1,36)$ & 29 & $-0,01$ & 0,04 & $-0,123 * * *$ \\
\hline
\end{tabular}

This table shows the means and medians (in parentheses) of investment and financing activities around the in the money convertible bonds calls (forced conversion) and around conversion of convertible bonds (voluntary conversion) between January 1994 and December 2009 on the Western European market. The first columns report levels of investment and financing activities and the last columns the changes relative to the year-1. Investment activities are capital expenditures scaled by the total assets of year-1. Financing activities are respectively new equity and new long-term debt scaled by the total assets of year-1. " $Z$ stat" indicates the $\mathrm{z}$ value of the Wilcoxon-Mann-Whitney test and the level of significance of eventual difference between the investment or financing activities for forced and voluntary conversion firms. "Chi2" reports the Pearson Chi2 value of the Mood's median test and the level of significance of eventual difference between the investment or financing activities for forced conversion firms and voluntary conversion firms. The column "Obs" reports the number of observations used at each date. The last column of this table reports the difference-in-differences estimator for the difference-in-differences model. *, ** and $* * *$ denote respectively the level of significance at $10 \%, 5 \%$ and $1 \%$. 


\subsubsection{In-the-money versus out-of-the-money calls (H2)}

We test in this paragraph the sequential financing theory by comparing in the money and out the money convertible bonds calls. Table 6 shows investment and financing activities (matched with median industries) for in the money call issuers versus out of the money call issuers.

Firstly, concerning the investment activity, we observe significant lower capital expenditures for in the money call issuers than those observed in the out of the money call group before the call date. In terms of changes, we notice a positive and significant change of $1.18 \%$ for the in the money call group compared with the positive change of $0.64 \%$ for the out of the money call group. The difference-in-differences model confirms that this result is due to the call decision. These results are in line with the sequential financial hypothesis of Mayers (1998).

Regarding financing activities, the results appear less significant. In terms of new equity issuance, we observe no difference between both groups except at year -2 where we can see a lower level for in the money call issuers than that obtained by out of the money call issuers. The new long-term debt issuance activity displays no significant differences except at year +1 , which demonstrates a significant positive change higher for in the money call firms than for out of the money call group.

Contrary to our prediction, we find that the investment and financing activities around the CB calls are similar for the ITM and OTM calling firms except for the change in investment levels. This lack of significance can be explained by the presence of asymmetric information as indicated in section 3 where we observed that the market to book ratio is higher for OTM firms than for ITM firms. OTM calls may then signal positive private information when the investors are not well informed of the presence of profitable investment opportunities. In this case, the investment option at the call date is considered being profitable and the prediction for ITM calling firms is also expected for the OTM calling firms. We test this assumption by conducting two complementary analyses: one on the market reaction following the call announcement and one on the post-call operating performance of the calling firms. The tables 10 and 11 report the results of this analysis (Cf. Annex).

As reported in Table 10, we find non-significant negative abnormal returns around the OTM CB call contrary to the signaling hypothesis of Cowan et al., (1993) which predict positive 
market reaction. Furthermore, the Mann-Whitney test fails to identify any difference between the market reaction for the forced conversion firms and the OTM calling firms.

We analyze the post-call operating performance of the calling firms three years after the call decision. The post-call performance is measured using two variables: EBITDA and PER ratio (Cf Table 11 for details on calculation of theses variables). The results are mixed. Firstly, when we consider the EBITDA we find no difference between the two groups for the three years following the call decision. However, the PER ratio indicates significant difference between the ITM and OTM calling firms after the calls. We find that OTM calling firms performs more than their industries but this over-performance is decreasing. Conversely, we find that ITM calling firms perform less than their industries and this under-performance tends to dissipate gradually after the call decision. The difference between the post-call operating performances between the two groups is significant at $5 \%$ level from the call date to the next two years. These results support partially the signaling hypothesis. In fact, when there is asymmetric information, the OTM calls can signal the presence of profitable investment option. This can explain why we find weak differences between the investment and financing activities of the ITM and OTM calling firms. In presence of positive private information, managers should prefer debt to equity in order to preserve the wealth of the existing shareholders. In line with this, we can see in Table 6 (Panel C) that OTM calling firms increase the debt financing one year before the call decision in anticipation of substitution of debt for equity. For ITM calling firms, the increase of the debt takes place one year after the calls, which indicates that the debt increase serves as additional financing as argued by Mayers (1998). Taken together, these results are in line with the sequential financing hypothesis. 
Table 6: Industry-matched investment and financing activities around convertible bonds calls (In the money versus out of the money calls)

\begin{tabular}{|c|c|c|c|c|c|c|c|c|c|c|c|c|c|c|}
\hline \multicolumn{8}{|c|}{ Investment and financing activities } & \multicolumn{7}{|c|}{ Changes in investment and financing activities } \\
\hline Period & ITM & Obs. & OTM & Obs. & Z stat & Chi2 & DID & ITM & Obs. & OTM & Obs. & Z stat & Chi2 & DID \\
\hline \multicolumn{15}{|c|}{ Panel A: Capital expenditures } \\
\hline-2 & $5.08(4.39)$ & 50 & $8.69(7.40)$ & 42 & $2.84 * * *$ & $6.31 * *$ & - & $0.14(0.07)$ & 50 & $1.69(0.17)$ & 41 & 0.76 & 0.09 & - \\
\hline-1 & $5.57(4.78)$ & 52 & $7.87(5.86)$ & 43 & $1.88 * *$ & 0.51 & - & $0.92(0.65)$ & 50 & $1.11(0.76)$ & 41 & -0.02 & 0.09 & - \\
\hline 0 & $6.27(5.47)$ & 54 & $7.59(5.08)$ & 48 & 0.26 & 0.16 & 0.038 & $1.18(0.48)$ & 52 & $0.64(0.14)$ & 43 & -1.42 & 0.88 & $0.051 *$ \\
\hline+1 & $5.97(4.66)$ & 57 & $7.52(5.01)$ & 48 & 0.28 & 0.23 & 0.062 & $-0.06(0.06)$ & 54 & $0.79(0.18)$ & 48 & 0.38 & 0.63 & 0.083 \\
\hline+2 & $5.24(4.13)$ & 57 & $7.26(5.04)$ & 48 & 1.25 & 0.23 & 0.089 & $-0.13(0.13)$ & 57 & $0.64(0.37)$ & 48 & 1.44 & 1.60 & 0.133 \\
\hline \multicolumn{15}{|c|}{ Panel B: New equity issuance } \\
\hline-2 & $2.17(0.20)$ & 49 & $2.92(0.36)$ & 43 & $1.84^{*}$ & $2.99 *$ & - & $-0.17(0.00)$ & 44 & $-0.09(0.00)$ & 38 & -0.70 & 0.23 & - \\
\hline-1 & $1.54(0.26)$ & 52 & $3.23(0.24)$ & 41 & 0.11 & 0.04 & - & $0.26(0.02)$ & 46 & $1.44(0.00)$ & 38 & -0.39 & 0.46 & - \\
\hline 0 & $2.90(0.37)$ & 54 & $3.06(0.40)$ & 44 & -0.30 & 0.09 & 0.046 & $1.46(0.14)$ & 49 & $1.43(0.01)$ & 38 & -0.76 & 1.45 & 0.028 \\
\hline+1 & $2.14(0.29)$ & 51 & $2.48(0.27)$ & 44 & 0.08 & 0.16 & 0.059 & $-0.40(-0.01)$ & 50 & $0.63(0.00)$ & 39 & -0.19 & 0.09 & 0.004 \\
\hline+2 & $1.61(0.27)$ & 52 & $0.80(0.27)$ & 47 & 0.30 & 0.01 & 0.080 & $-0.10(0.00)$ & 51 & $-1.07(0.00)$ & 44 & -0.25 & 1.11 & 0.015 \\
\hline \multicolumn{15}{|c|}{ Panel C: New long-term debt issuance } \\
\hline-2 & $8.66(2.33)$ & 46 & $6.53(2.65)$ & 37 & 1.00 & 0.10 & - & $0.64(0.00)$ & 44 & $-0.80(-0.94)$ & 34 & -0.52 & $3.34^{*}$ & - \\
\hline-1 & $10.06(2.46)$ & 47 & $12.51(4.46)$ & 38 & 1.16 & 0.28 & - & $5.25(0.00)$ & 45 & $8.20(1.20)$ & 35 & 0.90 & 2.32 & - \\
\hline 0 & $6.48(2.42)$ & 51 & 7.47 (3.77) & 43 & 0.98 & 0.04 & -0.024 & $0.23(0.00)$ & 45 & $-0.45(0.00)$ & 37 & -0.89 & 0.07 & -0.016 \\
\hline+1 & $9.23(3.14)$ & 53 & $5.05(0.93)$ & 41 & -1.03 & 0.39 & 0.030 & $3.69(0.18)$ & 50 & $0.02(-0.31)$ & 39 & $-1.70^{*}$ & $3.78^{*}$ & 0.079 \\
\hline+2 & $7.49(3.87)$ & 53 & $6.51(5.48)$ & 42 & 0.19 & 0.25 & 0.05 & $0.32(0.61)$ & 51 & $3.09(0.10)$ & 39 & 0.82 & 0.04 & 0.114 \\
\hline
\end{tabular}

This table shows the means and medians (in parentheses) of investment and financing activities around the exercise in the money (ITM) or out of the money (OTM) of the convertible bonds calls between January 1994 and December 2009 on the Western European market. The first columns report levels of investment and financing activities and the last columns the changes relative to the year-1. Investment activities are capital expenditures scaled by the total assets of year-1. Financing activities are new equity and new long-term debt scaled by the total assets of year-1. "Z stat" indicates the $\mathrm{z}$ value of the Wilcoxon-Mann-Whitney test and the level of significance of eventual difference between the investment or financing activities for ITM and OTM calling firms. "Chi2" reports the Pearson Chi2 value of the Mood's median test and the level of significance of eventual difference between the investment or financing activities for ITM and OTM call options. The column "Obs" reports the number of observations used at each date. The last column of this table reports the difference-in-differences estimator for the difference-in-differences model. *, $* *$ and $* * *$ denote respectively the level of significance at $10 \%, 5 \%$ and $1 \%$. 


\subsubsection{Robustness checks}

We perform additional analyses to confirm the previous results. Our objective is to introduce control variables in the difference-in-differences methodology. Moreover, as predicted by the Mayers' model, the conversion of convertible bonds should alleviate the firm's leverage and facilitate the issuance of new debt if necessary. We then further test a possible formal link between the investment and financing activities on the one hand and between equity and debt financings on the other hand. We also control for time and firm-specific effects by adding the year's dummies in our regression models. The difference-in-differences model is expressed as follows:

$\Delta$ Inv or Fin Level it $=\alpha_{i}+\beta(C B$ event dummy $)+\lambda X_{i t}+\varepsilon_{i t}$

Where $\Delta$ Inv or Fin Level $\boldsymbol{l}_{i t}$ is either the event date investment or financing level minus that of the preceding year of each firm $i$ and its industry depending on the comparison $(\mathrm{H} 1 \mathrm{a}, \mathrm{H} 1 \mathrm{~b}$ and $\mathrm{H} 2)$ at time $\mathrm{t}$,

CB event Dummy is the treatment dummy variable which is equal to 1 for calling firms (H1a), forced conversion firms (H1b) and in the money calling firms (H2) and 0 for non-calling firms (H1a), voluntary conversions firms (H1b) and out of the money calling firms (H2). $\boldsymbol{X}$ is the set of various control variables.

Table 7 shows the results of the comparison between calling and non-calling firms. In Models 2, we find that the change in new equity financing at the call dates has a significant positive impact on the variation of the investment activities for the calling firms but not for noncalling firms (significant coefficient of the interaction between variation of equity and call dummy). This result suggest that the positive variation of the investment level is explained by the positive variation of equity financing for the calling firms but this causal relationship is not true for non-calling firms. This finding cannot be found in a simple univariate analysis. This result supports the sequential financing hypothesis. We also find that the positive change of the new debt issuance has positive impact on the investment level when the firms early call their convertibles or at maturity. These two results are interesting because our predictions are based on the assumption that financing activities levels determine the investment levels. Unsurprising, cash is a determinant of the firms' new equity financing level: the more cash available internally there are, the lower the level of equity issuance (Models 3-4). From the Models 3-6, we find that the decisions to early call the convertible bonds do not lead to any difference in terms of 
financing (neither for new equity issuance nor for new debt financing). Furthermore, the financial leverage seems to have a significant positive impact on the firms' new equity variation at the convertible bonds calls. A possible explanation for this finding is that highly indebted companies tend to reduce their leverage by issuing more equity than less leveraged firms. Also in line with the alleviation of the debt burden, we find in Models 5 and 6 that the variation of the new debt issuance at the call dates decreases with the firms' leverage prior to the convertible bonds calls. In Model 6, we find that the increase in the new equity issuance resulted in a positive variation in new debt issuance for calling firms but not for non-calling firms. This finding is consistent with the sequential financing model because we hypothesize that calling firms are closer to firms that implement sequential financing than non-calling firms. And, according to Mayers (1998), change in new equity financing for these firms has a significant positive impact on the variation of the new debt financing when the calls occurred.

Table 8 shows the results of the comparison between forced and voluntary conversions firms. Overall, the results are the same as those reported in table 7 except two different but interesting findings. First, we find that the variation of the equity financing positively impacts the new debt financing independently of whether the conversion is forced or voluntary. This result supports Mayers (1998) hypothesis. However, when we analyze this relationship separately, we find for firms that forced the conversion of their bonds a negative relationship between the variation of the new equity financing and the new debt financing level. We can explain this difference by the fact that the call option allows forced conversions firms to control issuance costs. Firms that incur high financing costs can prefer voluntary conversion because forced conversion is expensive and can lead to financial distress (see Jaffee and Shleifer, 1990). In line with this, Table 3 (Panel B) shows that voluntary conversion firms are small firms compared to forced conversions firms (difference is statistically significant at $1 \%$ level). Second, we find that the cash level before the conversion of the convertible bond has positive impact on the new equity financing unlike what we report in Table 7. This difference can be explained by the homogeneity of the two subsamples in the table 8 compared to those in the Table 7. In the Table 8, the two groups have at call or maturity dates in the money investment option which require additional financings. This is not the case for the groups of calling and non-calling firms, the financings patterns are different across the firms. This difference can explain why the cash flow available prior the redemptions (calls or conversions) have different impact on the new equity financing. The relationship in the case of conversions event is in line with the sequential hypothesis because the conversions signal profitable investment option 
which required new financing. In the case of the simple redemptions events (calls or conversion), the relationship is more nuanced. Finally, in line with the Mayers' theory we find that the companies exercising their call option ITM have higher investment activities (table 9 model 2).

Overall, after controlling for time fixed effects and other control variables, we find partial evidence in line with the sequential financing hypothesis of Mayers (1998). These results are: (1) changes in equity and debt financings at the convertible bonds calls have a significant positive impact on the variation in investment activity and (2) changes in equity financing have a significant impact on the variation in new debt financing for calling firms but not for noncalling firms. However, contrary to what is expected by the sequential financing theory, we find a negative impact of the exercise of the call (in the three hypotheses) on the level of debt financing.

The main difference between alternatives theories and that of Mayers (1998) is that, in the first, convertibility is used to solve financing problems at the time of issue whereas in the Mayers' model convertibility solves future financing problems. It is the reason why in the study we focus on the firms' behavior at the call date. In the adverse selection cost models of Brennan and Kraus (1987), Brennan and Schwartz (1988) and Stein (1992), managers and investors disagree about the risk or the value of the company at the time the convertible bond is issued and therefore no additional financing and investment activities should be observed during the life of the convertible bonds. The call feature plays an important role in Stein's model since it gives opportunity to time the market and issue equity in the backdoor. Nevertheless, in Stein's approach, the call date should not be associated with higher investment activities. Following the model of Green (1984), convertible bonds should prevent managers from investing in negative net present value projects, so in this case we should observe rather less than more investment activities during the life or at maturity of the bond. As, in general, we do not find a clear and significant positive impact of the exercise of the call on the level of new investment we question the relevance of the Mayers' theory compared to the approaches proposed by Stein (1982) or Green (1984).

Moreover, Nyborg (1995) insists on the fact that the benefits of callable convertible bonds as delayed equity are preserved only if conversion is voluntary. In the Harris and Raviv (1985) signaling models, in the money calls represent bad news about the calling firm's prospects. It is a way for the management to force the conversion into the overpriced equity. In contrast, out of the money calls signal the ability of the company to raise enough cash to redeem 
the bond (Cowan et al., 1993). A new debt issue at a lower cost could be associated with the call. As we do not observe a significant increase in new debt (but rather a decrease in debt issuance), we can assert that our results are not driven by this alternative theory. 
Table 7: Relation between investment and financing activities: Calling versus non calling

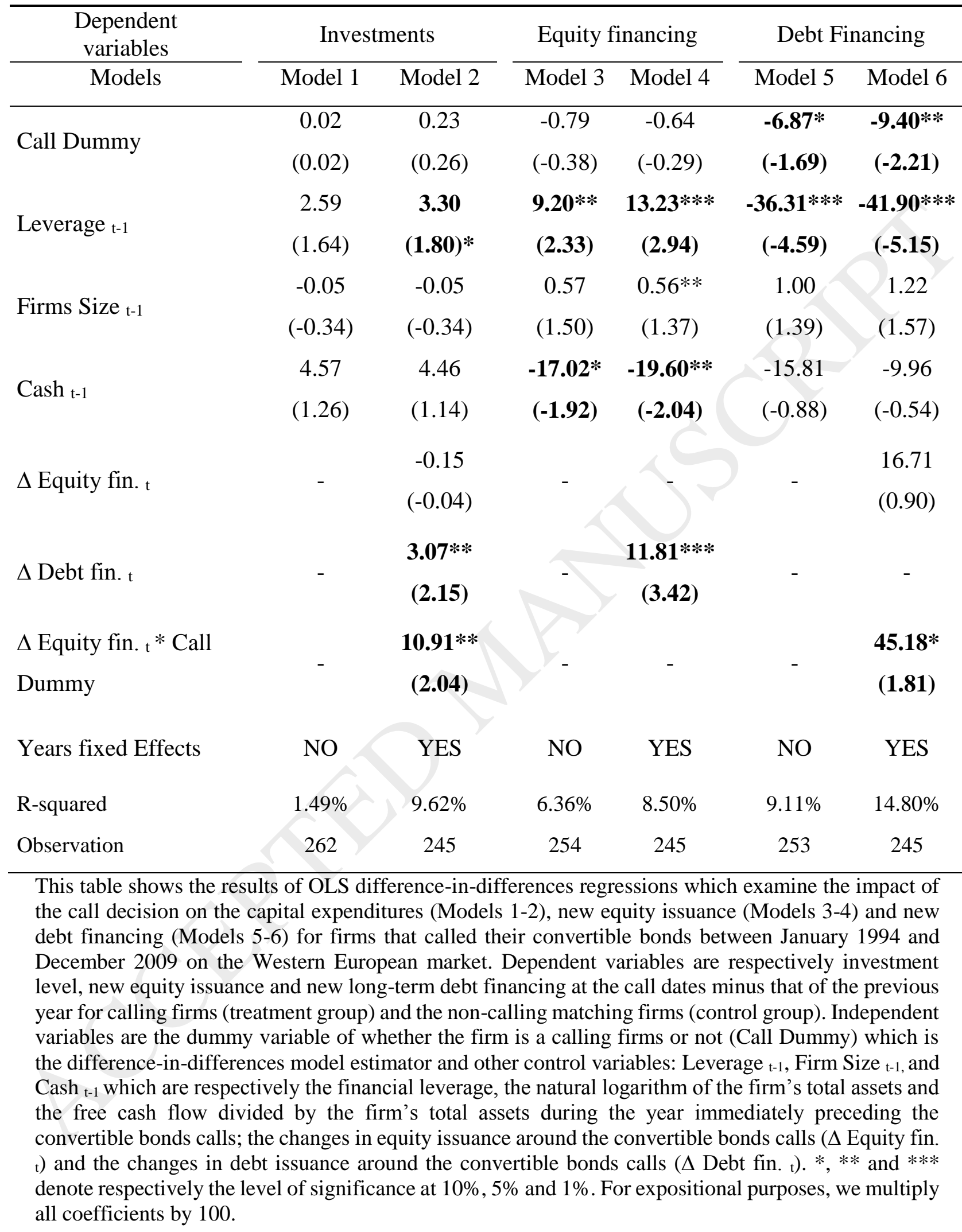


Table 8: Relation between investment and financing activities: Forced versus voluntary conversions

\begin{tabular}{|c|c|c|c|c|c|c|}
\hline $\begin{array}{l}\text { Dependent } \\
\text { variables }\end{array}$ & \multicolumn{2}{|c|}{ Investments } & \multicolumn{2}{|c|}{ Equity financing } & \multicolumn{2}{|c|}{ Debt Financing } \\
\hline Models & Model 1 & Model 2 & Model 3 & Model 4 & Model 5 & Model 6 \\
\hline Forced Call & -0.43 & -0.05 & 0.99 & 1.33 & -5.81 & -6.67 \\
\hline Dummy & $(-0.54)$ & $(-0.07)$ & $(0.46)$ & $(0.54)$ & $(-1.00)$ & $(-1.09)$ \\
\hline Leverage $_{\mathrm{t}-1}$ & $\begin{array}{c}4.23 * * * \\
(2.98)\end{array}$ & $\begin{array}{c}5.86 * * * \\
(3.13)\end{array}$ & $\begin{array}{c}19.92 * * * \\
(5.22)\end{array}$ & $\begin{array}{c}17.97 * * * \\
(3.45)\end{array}$ & $\begin{array}{c}-35.57 * * * \\
(-3.10)\end{array}$ & $\begin{array}{c}-34.97 * * \\
(-2.56)\end{array}$ \\
\hline Firms Size $t-1$ & $\begin{array}{c}0.09 \\
(0.70)\end{array}$ & $\begin{array}{c}0.05 \\
(0.36)\end{array}$ & $\begin{array}{c}0.02 \\
(0.53)\end{array}$ & $\begin{array}{c}0.13 \\
(0.29)\end{array}$ & $\begin{array}{c}0.73 \\
(0.72)\end{array}$ & $\begin{array}{c}0.56 \\
(0.51)\end{array}$ \\
\hline Cash $_{\mathrm{t}-1}$ & $\begin{array}{r}-0.30 \\
(-0.33)\end{array}$ & $\begin{array}{c}-1.19 \\
(-0.33)\end{array}$ & $\begin{array}{c}39.54 * * * \\
(12.28)\end{array}$ & $\begin{array}{c}37.71 * * * \\
(7.31)\end{array}$ & $\begin{array}{c}84.66 * * * \\
(9.11)\end{array}$ & $\begin{array}{l}5.43 \\
(0.2)\end{array}$ \\
\hline$\Delta$ Equity fin. $\mathrm{t}$ & - & $\begin{array}{c}-6.50 \\
(-0.88)\end{array}$ & & & - & $\begin{array}{c}1.49 * * * \\
(2.79)\end{array}$ \\
\hline$\Delta$ Debt fin. $\mathrm{t}$ & - & $\begin{array}{c}4.93 * * * \\
(3.27)\end{array}$ & & $\begin{array}{r}4.84 \\
(1.11)\end{array}$ & - & - \\
\hline $\begin{array}{l}\Delta \text { Equity fin. } \mathrm{t}^{*} \\
\text { ITM Call Dummy }\end{array}$ & - & $\begin{array}{l}15.34 * \\
(1.90)\end{array}$ & & - & - & $\begin{array}{l}-1.51 * * \\
(-2.57)\end{array}$ \\
\hline Years fixed Effects & $\mathrm{NO}$ & YES & $\mathrm{NO}$ & YES & NO & YES \\
\hline R-squared & $10.89 \%$ & $24.31 \%$ & $85.62 \%$ & $84.16 \%$ & $55.29 \%$ & $58.90 \%$ \\
\hline Observation & 102 & 97 & 100 & 97 & 99 & 97 \\
\hline
\end{tabular}

This table shows the results of OLS difference-in-differences regressions which examine the impact of the call decision on the capital expenditures (Models 1-2), new equity issuance (Models 3-4) and new debt financing (Models 5-6) for firms that forced the conversion of their convertible bonds and for firms in which investors voluntary convert the bonds between January 1994 and December 2009 on the Western European market. Dependent variables are respectively investment level, new equity issuance and new long-term debt financing at the call dates minus that of the previous year for forced conversion firms (treatment group) and for voluntary conversion firms (control group). Independent variables are the dummy variable of whether the conversion is forced or not (Forced Call Dummy) which is the difference-in-differences model estimator and other control variables: Leverage ${ }_{t-1}$, Firm Size ${ }_{t-1}$, and Cash $\mathrm{t}-1_{1}$ which are respectively the financial leverage, the natural logarithm of the firm's total assets and the free cash flow divided by the firm's total assets during the year immediately preceding the convertible bonds calls; the changes in equity issuance around the convertible bonds calls ( $\Delta$ Equity fin. t) and the changes in debt issuance around the convertible bonds calls ( $\Delta$ Debt fin. $\left.{ }_{\mathrm{t}}\right)$. *, ** and *** denote respectively the level of significance at $10 \%, 5 \%$ and $1 \%$. For expositional purposes, we multiply all coefficients by 100 . 
Table 9: Relation between investment and financing activities: in the money versus out of the money call option

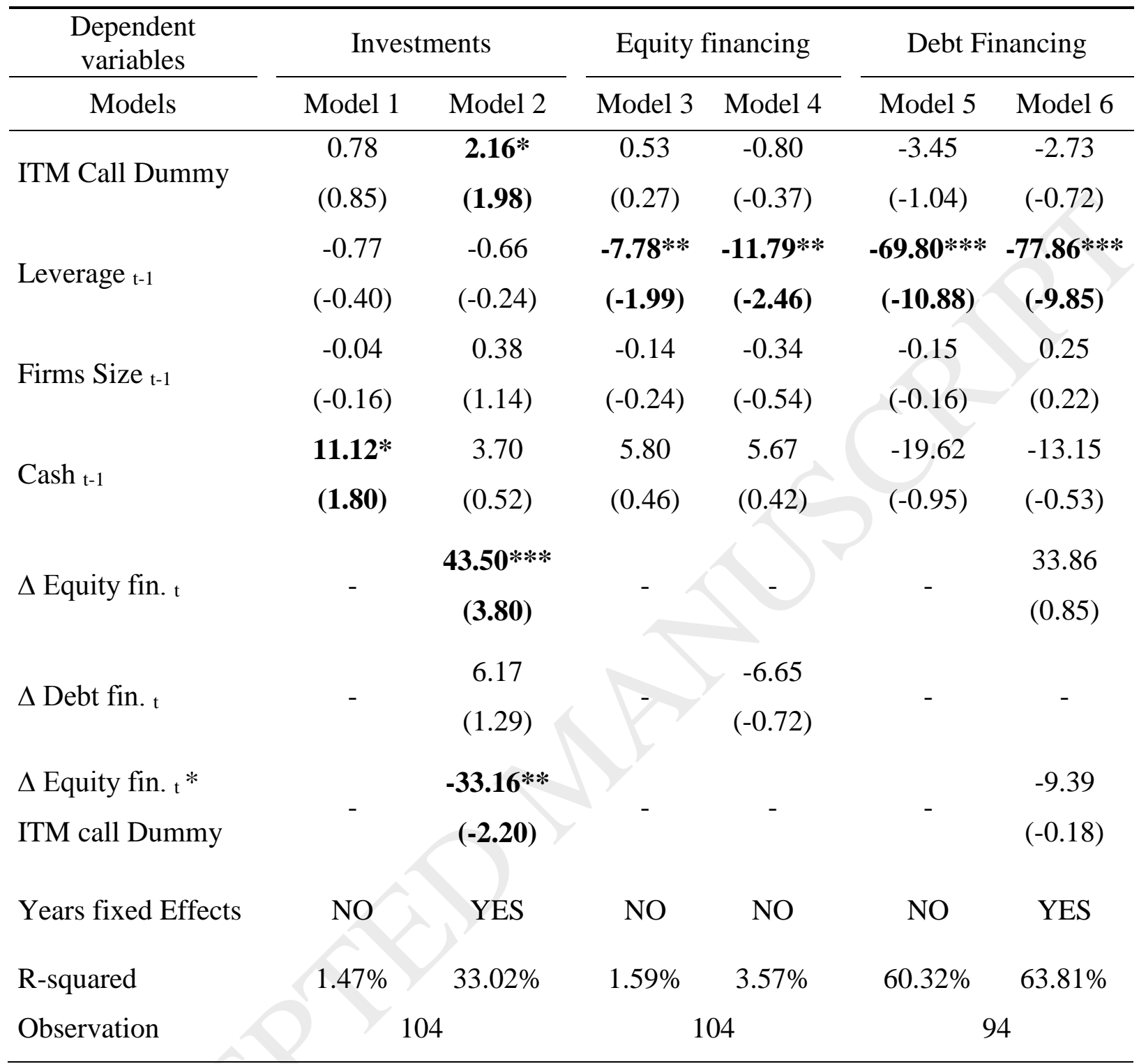

This table shows the results of OLS difference-in-differences regressions which examine the impact of the call decision on the capital expenditures (Models 1-2), new equity issuance (Models 3-4) and new debt financing (Models 5-6) for firms that called or redeemed their convertible bonds in- or out-of-themoney between January 1994 and December 2009 on the Western European market. Dependent variables are respectively investment level, new equity issuance and new long-term debt financing at the call dates minus that of the previous year for ITM calls and for OTM calls (control group). Independent variables are the dummy variable of whether the call is made when the convertible bonds was ITM (ITM Call Dummy) which is the difference-in-differences model estimator and other control variables: Leverage $\mathrm{t}_{\mathrm{t}-1}$, Firm Size $\mathrm{t}-1$, and Cash $\mathrm{t}-1$ which are respectively the financial leverage, the natural logarithm of the firm's total assets and the free cash flow divided by the firm's total assets during the year immediately preceding the convertible bonds calls; the changes in equity issuance around the convertible bonds calls ( $\Delta$ Equity fin. $t$ ) and the changes in debt issuance around the convertible bonds calls $\left(\Delta\right.$ Debt fin. $\left.{ }_{\mathrm{t}}\right) . *, * *$ and $* * *$ denote respectively the level of significance at $10 \%, 5 \%$ and $1 \%$. For expositional purposes, we multiply all coefficients by 100 . 


\section{Conclusion}

The sequential financing theory of Mayers (1998) supports that firms facing high overinvestment costs choose callable convertible bonds in order to implement an optimal sequential financing strategy. In this context, the call provision embedded in the convertible bonds is therefore a key feature in the design of such security. In this study, we pointed the importance of this call provision by comparing the investment and financing activities of the Western European firms around the exercise dates (forced conversion and conversion at maturity).

Firstly, we compare the investment activities between firms that called their convertibles and those that did not call. We observe only a slight difference between the two groups leading to a weak support to the sequential financing strategy. Secondly, the comparison of investment activities between forced and voluntary conversion does not reveal significant differences. Furthermore, unlike Alderson et al. (2006), we find that in the money calling firms increase their investment more than out of the money calling firms around the convertible bonds calls but we do not observe significant differences between the financing activities of these two groups. The higher level of informational asymmetry for firms that call Out of the Money their bonds may explain this result. Moreover, we find that the increase in new equity financing in case of the call exercise (in all cases or in the money) has a significant positive impact on investments. Secondly, we observe a significant difference in new equity issuances only for the comparison between calling and non-calling firms. We also find a positive impact of the call decision on the change of the new debt issuance at the call dates.

Our study places special emphasis on the role of call provision of convertible bonds in the Western European market using different methodological approaches. Unlike previous studies, we use difference-in-differences models that enable us to impute the change in investment and financing activities of the calling firms directly to the call decision and to introduce control variables to explain the changes in the investment financing activities.

Our empirical results highlight weak supports for the sequential financing theory of Mayers (1998). More precisely, we do not find that call provision plays a significant role (in general) in sequential financing strategy. The hypothesis of differences between US and European firms in terms of investment opportunities, information asymmetry and issuing costs, could provide explanations to these results. Thus, one avenue for further research will be to test 
the Mayers sequential financing hypothesis by comparing US and European callable CB issuers. 


\section{References}

Alderson, M.J., Betker, B.L., Sotck, D.R., 2006, Investment and financing Activity Following Calls of Convertible Bonds, Journal of Banking \& Finance, 30:895-914

Asquith, P., Mullins, D. 1991, Convertible debt: corporate call policy and voluntary conversion, Journal of Finance, 46, 1273-1286.

Bancel, F. Mittoo, U.R. 2004, Why Do European Firms Issue Convertible Debt? European Financial Management, 10, 2: 339-374

Bancel, F., Mittoo, U. R., Zhang, Z., 2009. The Geography of European Convertible Bonds: Why Firms Issue Convertibles? Working Paper

Billingsley, R.S., Smith, D.M., 1996, Why Do Firms Issue Convertible Debt? Financial Management 25, 93-99

Brennan, M., Kraus, A., 1987, Efficient Financing under Asymmetric Information, The Journal of Finance 42, 1225-1243

Brennan, M.J., Schwartz, E.S., 1988, The Case for Convertibles, Journal of Applied Corporate Finance Vol 1, 55-64

Brown, S.J., Grundy, B.D., Lewis, C.M., Verwijmeren, P., 2012, Convertibles and Hedge Funds as Distributors of Equity Exposure, The Review of Financial Studies 25, 3077-3112

Card, D., Krueger, A.B., 1994, Minimum Wages and Employment: A Case Study of the FastFood Industry in New Jersey and Pennsylvania. The American Economic Review 84, 772793.

Chang, S.-C., Chen, S.-S., Liu, Y., 2004, Why firms Use Convertibles: A Further Test of the Sequential-financing Hypothesis. Journal of Banking \& Finance, 28:1163-1183

Constantinides, G.M., Grundy, B.D., 1987. Call and conversion of convertible corporate bonds: theory and evidence, working paper, University of Chicago.

Cowan, A.R., Nayar, N. Singh A.K. 1993. Calls of Out-of-the-Money Convertible Bonds. Financial Management, 22: 106-116.

De Jong, A., Duca, E., Dutordoir, M., 2013, Do Convertible Bond Issuers Cater to Investor Demand? Financial Management 42, 41-78

Dutordoir, M., Van De Gucht, L., 2004, Are European Convertibles More Debt-Like than the US Issues? An Empirical Analysis, Review of Business and Economic Literature, 4, 533 568. 
Dutordoir, M., Lewis, C., Seward, J., Veld, C., 2014, What We Do and do not Know about Convertible Bond Financing, Journal of Corporate Finance 24, 3-20

Graham, J.R., Harvey, C.R., 2001, The Theory and Practice of Corporate Finance: Evidence from the Field, Journal of Financial Economics, 60, 187-243

Green, R., (1984). Investment Incentives, Debt, and Warrants. Journal of Financial Economics, 13:115-136.

Harris, M., Raviv, A., 1985, A Sequential Signalling Model of Convertible Debt Call Policy, The Journal of Finance 40, 1263-1281

Ingersoll, J., 1977, An Examination of Corporate Call Policies on Convertible Securities, Journal of Finance XXXII, 463-478

Jaffee, D., Shleifer, A., 1990, Costs of Financial Distress, Delayed Calls of Convertible Bonds, and the Role of Investment Banks, The Journal of Business 63, S107-S123

Jensen, M.C., 1986, Agency Costs of Free Cash Flow, Corporate Finance, and Takeovers, American Economic Review, 76(2):323-329

King, T.-H.D., Mauer, D.C., 2014, Determinants of Corporate Call Policy for Convertible Bonds, Journal of Corporate Finance, 24:112-134

Korkeamaki, T.P., Moore, W.T., 2004, Convertible Bond Design and Capital Investment: The Role of Call Provisions, The Journal of Finance, 59:391-405

Lewis, C.M., Rogalski, R.J., Seward, J.K., 2001, The Long-Run Performance of Firms that Issue Convertible Debt: An Empirical Analysis of Operating Characteristics and Analyst Forecasts, Journal of Corporate Finance 7, 447-474

Mayers, D., 1998, Why Firms Issue Convertible Bonds: The Matching of Financial and Real Investment Options, Journal of Financial Economics, 47:83-102

Nyborg, K.G., 1995, Convertible Debt as Delayed Equity: Forced Versus Voluntary Conversion and The Information Role of Call Policy. Journal of Financial Intermediation, 4, 358-395

Roberts, M.R., Whited, T.M., 2012, Endogeneity in Empirical Corporate Finance. Simon School Working Paper No FR 11-29.

Stein, J.C., 1992. Convertible Bonds as Backdoor Equity Financing. Journal of Financial Economics, 32, 3-21 
Table 10: Convertible bonds call announcement returns

\begin{tabular}{|c|c|c|c|c|c|}
\hline & \multicolumn{2}{|c|}{ ITM Calls } & \multicolumn{2}{|c|}{ OTM Calls } & \multirow{2}{*}{$\begin{array}{c}\text { Mann- } \\
\text { Whitney } \\
\text { z-stat }\end{array}$} \\
\hline & $\begin{array}{c}\text { Abnormal } \\
\text { Returns }\end{array}$ & $\begin{array}{c}\text { Wilcoxon } \\
\text { z-stat }\end{array}$ & $\begin{array}{c}\text { Abnormal } \\
\text { Returns }\end{array}$ & $\begin{array}{c}\text { Wilcoxon } \\
\text { z-stat } \\
\end{array}$ & \\
\hline \multicolumn{6}{|c|}{ Daily Abnormal Returns } \\
\hline-3 & $-0,20(-0,09)$ & 0,25 & $-0,13(-0,19)$ & 0,53 & $-0,37$ \\
\hline-2 & $-0,01(0,23)$ & $-0,68$ & $-0,12(-0,04)$ & 0,61 & $-0,85$ \\
\hline-1 & $-0,23(-0,03)$ & 0,55 & $0,36(0,20)$ & $-0,27$ & 0,62 \\
\hline 0 & $-0,10(0,05)$ & $-0,14$ & $-0,74(-0,28)$ & 1,41 & 1,00 \\
\hline 1 & $-0,51(-0,15)$ & 1,05 & $-0,63(-0,02)$ & 0,98 & 0,19 \\
\hline 2 & $0,23(0,08)$ & $-0,83$ & $-0,41(-0,07)$ & 0,54 & $-0,94$ \\
\hline 3 & $0,16(0,30)$ & $-1,49$ & $-0,08(0,32)$ & $-0,49$ & 0,00 \\
\hline \multicolumn{6}{|c|}{ Average Abnormal Returns } \\
\hline$-1+1$ & $-0,27(-0,07)$ & 0,67 & $-0,23(-0,11)$ & 0,91 & $-0,12$ \\
\hline$-2+2$ & $-0,05(0,03)$ & $-0,45$ & $-0,24(-0,20)$ & 1,44 & $-1,14$ \\
\hline$-3+3$ & $-0,06(-0,05)$ & 0,04 & $-0,20(-0,21)$ & 1,01 & $-0,95$ \\
\hline
\end{tabular}

This table shows the means and medians (in parentheses) of abnormal returns around the calls of the $\mathrm{CB}$ by Western European firms. 0 is the call announcement date. The Wilcoxon sign-rank test is used to test the null hypothesis that the observed returns equal the normal returns. Normal returns are estimated using the market model over -281;-31 trading days. The market index used is the DJ Stoxx 1800. 
Table 11: Post-call financial performance

\begin{tabular}{cccc}
\hline Period & ITM calling firms & OTM calling firms & $\begin{array}{c}\text { Mann-Whitney } \\
\text { z-stat }\end{array}$ \\
\hline \multicolumn{2}{c}{ Earnings Before Interest, Taxes, Depreciation and Amortization (EBITDA) } \\
0 & $0,35(-0,22)$ & $-1,17(0,28)$ & $-1,19$ \\
1 & $-0,45(-0,10)$ & $-0,44(0,67)$ & 0,12 \\
2 & $0,21(0,36)$ & $0,17(1,18)$ & 0,08 \\
3 & $0,75(-0,47)$ & $0,51(-0,18)$ & $-0,02$ \\
Price Earnings Ratio (PER) & & $\mathbf{2 , 2 3 * *}$ \\
0 & $-2,75(-5,21)$ & $4,15(-0,93)$ & $\mathbf{2 , 3 0 * *}$ \\
1 & $-2,39(-5,28)$ & $5,30(-0,49)$ & $\mathbf{2 , 2 7 * *}$ \\
3 & $-1,84(-4,48)$ & $2,35(-0,69)$ & 0,23 \\
\hline
\end{tabular}

This table shows the means and medians (in parentheses) of some post-call operating performance indicators for CB calling firms. Operating performance indicators are industry-adjusted EBITDA scaled by the total assets and PER. We industry-adjust these variables by subtracting industry median EBIDTA or PER from those of the sample firms. Industries are constructed using the 4-digits S\&P GICS classification and from the DJ Stoxx 1800 market index. The Wilcoxon rank-sum test (Mann-Whitney test) is used to assess eventual difference between the industry-adjusted post-call performance of the two groups. $* *$ denote the significance at $5 \%$ levels. 